\title{
Diagnostic performance evaluation of post- operative serum calcitonin (CT) levels as a factor for good prognosis in medullary thyroid carcinoma (MTC)
}

\author{
Danuta Gąsior-Perczak*, Aldona Kowalska, Iwona Pałyga, Anna Słuszniak, Ryszard Mężyk, Stanisław Góźdź
}

From 4th Congress of the Polish Thyroid Association 2013

Lodz, Poland. 11-13 April 2013

\section{Introduction}

The 10 -year survival rate of MTC patients is $65 \%$. Metastases may occur even many years after the surgery. Thus, MTC patients require constant oncological monitoring. The aim of the study was to assess the post-operative levels of basal and stimulated CT, as a prognostic factor for good prognosis in MTC patients.

\section{Patients}

The study included 67 MTC patients (53 women and 14 men, aged 16-77 years) treated in our hospital (from 1996 to 2012).

\section{Methods}

Basal and stimulated CT levels were measured 3 months after the surgery. The follow-up was continued for average 7.2 years (1-16 years). In the event of increasing CT levels, imaging studies were performed to detect metastases. Correlation between the occurrence or lack of metastases and CT levels 3 months after the surgery was assessed.

\section{Results}

Metastases to cervical lymph nodes were found in 6 patients 1 to 10 years after the surgery, one patient had metastases to ovary 11 years after the surgery, one patient had metastases to liver 5 years after the surgery and 6 cases had a constant elevation of CT levels without any findings in imaging studies. 4 patients died 1-4 years after the surgery. Post-operative CT levels in all patients mentioned above were elevated (basal CT 20-518 pg/ml; stimulated CT $199-3823 \mathrm{pg} / \mathrm{ml}$ ) In the rest of the patients

Holycross Cancer Centre, Kielce, Poland with normal CT level no metastases or increase in CT levels were found during the follow-up (basal CT $<2.0-12$ $\mathrm{pg} / \mathrm{ml}$; stimulated $<2.0-19.7 \mathrm{pg} / \mathrm{ml})$.

\section{Conclusions}

1. Normal basal and stimulated CT levels 3 months after the MTC surgery correlate very well with a good prognosis and lack of late metastases.

2. Further studies are required to confirm that patients with normal post-operative $\mathrm{CT}$ levels can be released from oncological monitoring.

Published: 5 April 2013

doi:10.1186/1756-6614-6-S2-A17

Cite this article as: Gąsior-Perczak et al: Diagnostic performance evaluation of post-operative serum calcitonin (CT) levels as a factor for good prognosis in medullary thyroid carcinoma (MTC). Thyroid Research 2013 6(Suppl 2):A17.

Submit your next manuscript to BioMed Central and take full advantage of:

- Convenient online submission

- Thorough peer review

- No space constraints or color figure charges

- Immediate publication on acceptance

- Inclusion in PubMed, CAS, Scopus and Google Scholar

- Research which is freely available for redistribution 